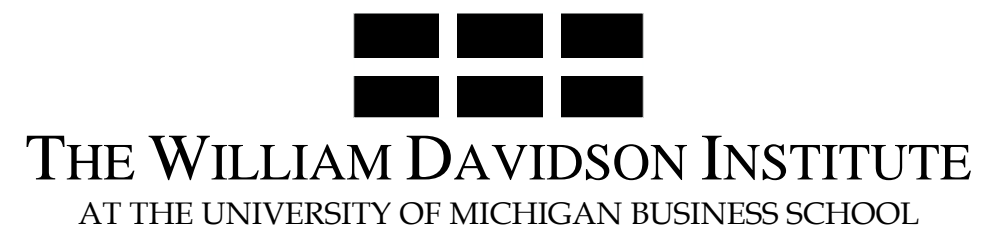

AT THE UNIVERSITY OF MICHIGAN BUSINESS SCHOOL

\title{
The Determinants of Asset Stripping: Theory and Evidence From the Transition Economies
}

\author{
By: Nauro F. Campos and Francesco Giovannoni
}

William Davidson Institute Working Paper Number 786

August 2005 


\title{
THE DETERMINANTS OF ASSET STRIPPING: THEORY AND EVIDENCE FROM THE TRANSITION ECONOMIES*
}

\author{
Nauro F. Campos \\ Brunel University, CEPR and \\ WDI-University of Michigan \\ nauro.campos@brunel.ac.uk
}

\author{
Francesco Giovannoni \\ Department of Economics and CMPO \\ University of Bristol \\ francesco.giovannoni@bris.ac.uk
}

This version: August 2005

\begin{abstract}
During the transition from plan to market, managers and politicians succeeded in maintaining control of large parts of the stock of socialist physical capital. Despite the obvious importance of this phenomenon, there have been no efforts to model, measure and investigate this process empirically. This paper tries to fill this gap by putting forward theory and econometric evidence. We argue that asset stripping is driven by the interplay between the firm's potential profitability and its ability to influence law enforcement. Our econometric results, for about 950 firms in five transition economies, provide support for this argument.
\end{abstract}

Keywords: Asset stripping, law enforcement, corruption, transition. JEL Codes: H82, K42, O17, P26, P31.

* The authors would like to thank Jan Fidrmuc, Klarita Gërxhani, Barry Ickes, Eliana La Ferrara, Massimo Morelli, Jeffrey Nugent, James Robinson, Gérard Roland, Mark Schaffer, Jon Temple, Daniel Treisman, Boris Vujcic, Romain Wacziarg, an anonymous referee and seminar participants at the University of Bristol, The World Bank, EPCS (Lago Maggiore) and ESRC-DESG Meetings (Nottingham), Political Economy of Transition Workshop (Bonn), PET Conference (Paris), NEUDC Meetings (Williamstown), Royal Economic Society Meetings (Warwick) and CEPR Transition Workshop (London) for valuable comments on previous versions. Very special thanks to Chris Woodruff for the data used in this study. All remaining errors are entirely our own. 
You don't know life. No one lives on wages alone.

I remember in my youth we earned money by unloading railroad freight cars. So, what did we do? Three crates or bags unloaded and one for ourselves.

That is how everybody lives in [our] country.

Leonid Brezhnev, quoted in Kornai (1992)

\section{INTRODUCTION}

One of the least pleasant surprises of the transition from centrally-planned to market economy in Eastern Europe and the former Soviet Union was the extent to which managers and politicians were able to maintain control of the stock of socialist physical capital without paying the full market prices for those "privatized" assets. We define this process as asset stripping. Although its significance is widely recognized, ${ }^{1}$ there are no systematic efforts to model, measure and understand it empirically. This paper tries to fill this gap.

There are at least three reasons to study the process of asset stripping. One is that an understanding of the determinants and consequences of asset stripping can throw light on the relationship economic reform and performance in a weak institutional setting (Rodrik, 1996). Various mechanisms support a potential negative effect of asset stripping on economic performance in such setting. For instance, asset stripping diminishes political support for reform, maintains an inefficient allocation of talent and stifles the demand for the rule of law and for clearly defined property rights (Sonin, 2003).

Another reason is that asset stripping is important in understanding economic performance during the transition from plan to market. The main stylized fact of the transition was the dramatic fall of per capita output (Campos and Coricelli, 2002). Although a number of explanations have been offered, the one that has enjoyed the most success is

\footnotetext{
${ }^{1}$ Roland notes that an unintended consequence of various mass privatization programs in transition economies was the widespread stripping of assets from public corporations for private uses (2002, p. 35). Hoff and Stiglitz (2004) observe that "the transfer of state property to private agents was accompanied by the stripping of Russia's assets." Stiglitz (2000) uses "looting” to describe the process of appropriation of physical and financial assets in Central and Eastern Europe. Johnson et al. (2000) define "tunneling" as the transfer of assets and profits out of firms for the benefit of their controlling shareholders in transition economies. Black et al. (2000), Freeland (2000), Ganev (2001) and Goldman (2003) provide detailed case study evidence of asset stripping in transition economies.
} 
arguably that based on the notion of "disorganization." According to Blanchard and Kremer (1997), disorganization causes a fall in output because the existing production chains break down. Consider a producer of an intermediary input that under central planning is only allowed to sell to a certain company. The collapse of central planning means this producer can now search for other customers. In successfully doing that (say by exporting), the supply chain breaks down, disorganization emerges, and output shrinks. Asset stripping is another possible cause of such breakdowns.

A final reason is that an understanding of asset stripping in the privatization experience of transition economies may lead to important lessons for privatization in other contexts. Indeed, as we will argue below, our analysis emphasizes the role of bad incentives for public officials and weak corporate governance in state owned enterprises. We believe these to be relevant in developing countries as well.

The objective of this paper is three-fold: (a) to construct a simple model of asset stripping, (b) to offer an empirical measure of the phenomenon, and (c) to test empirically the main implications from the model. We define asset stripping as the process of obtaining assets without paying the full market price for them. We focus on former State Owned Enterprises (SOEs) because their weak corporate governance makes them a particularly vulnerable target for asset strippers. ${ }^{2}$ Our model generates two main insights. The first is that a firm's ability to influence law enforcement officials through bribes or simply through political clout is an important determinant of asset stripping, even when law enforcement is potentially effective. A second insight is that there is a non-linear relationship between the potential profitability of the assets in question and the decision to strip them.

In order to measure the extent of asset stripping, we use data from a survey of directors (CEOs) of manufacturing firms in Poland, Slovakia, Romania, Ukraine and Russia. The survey took place in 1997 and covered about 1000 firms. We restrict our sample to firms that are not spin-offs from state enterprises (that is, our sample contains only start-ups or newly created private firms). According to our measure of asset stripping, the use of stripped assets is significantly more extensive in Russia and Ukraine than in Poland, Slovakia and Romania. The econometric results support the notion that (political or

\footnotetext{
${ }^{2}$ There is plenty of anecdotal evidence to suggest that control was so weak that SOE insiders sold the assets to their friends or even themselves. See Stiglitz (2000) for additional discussion of this point.
} 
financial) clout is an important determinant of the use of stripped assets. The results also strongly support a non-linear relationship between potential profitability and the decision to strip assets. Further, these results are robust to various sensitivity checks including different estimators and different measures of all key variables in the model.

The related literature is large, yet almost exclusively theoretical. Hoff and Stiglitz (2004) show how asset strippers have a low demand for the rule of law even if it is in their collective interest to have high levels of protection for property rights. In the model put forward by Tornell and Lane (1999), the existence of non-cooperative powerful groups generates, in an environment with weak institutions, a redistributive struggle and, as a result, a greater share of resources ends up in nontaxable inefficient activities. There is also an important related literature, on the role of law enforcement in transition (see, among others, Roland and Verdier, 2003).

This paper is organized as follows. In the next section, we introduce the theoretical framework. Section 3 presents the data set and our measure of asset stripping in transition economies. Section 4 discusses the empirical results. Section 5 concludes.

\section{THEORETICAL FRAMEWORK}

Early in the transition from centrally planned to market economy assets from state-owned enterprises (SOEs) became available for private ownership. We present a simple model where the actors are the government (central or local) and (potential) buyers for these assets. We look at a stylized situation where similar quality assets are available from both SOEs and the (international) private sector. We assume that SOEs have insiders (e.g. bureaucrats or managers) who enjoy significant control over the assets. These insiders have much better information about a buyer's willingness to pay for the assets than state officials. We assume that both this informational asymmetry and insiders' level of control are less significant in the private sector. With this assumption we wish to capture the fact that (a) active oversight of management will be inherently stronger in the private sector and (b) to the extent that private ownership is also foreign ownership, there will be much more experience in corporate governance. ${ }^{3}$ For our purposes, one important consequence of these assumptions is that insiders in SOEs will be able to sell their assets at a price that is lower than the price

\footnotetext{
3 Tighter control on management has often been indicated as one of the main rationales for the privatization process in the first place. See Roland (2000) for a detailed discussion.
} 
buyers would have to pay anyone in the private sector, possibly in exchange for a bribe. We call this asset stripping. Clearly, buyers still have the option of acquiring the assets from the private sector at the market price: as we will show below, this may be the preferred option if there is a significant risk that the government will enforce the law against them. We call this second option, restructuring. ${ }^{4}$ Obviously, asset stripping will not always have to involve the acquisition of SOE assets, but what is crucial about our stylized assumption is that asset stripping is more likely when assets from SOEs are involved. ${ }^{5}$

Given the various privatization methods used in transition economies and our intent to construct a theory of asset stripping that holds in a cross-country framework, we will not model explicitly the market or bargaining processes behind asset stripping and restructuring, but we will provide a reduced form set-up where the results of this process are reflected in our assumptions about the returns each of the two possibilities generates.

In our model, buyers are firms looking at the possibility of adding new assets to their portfolio. We first assume that in the status quo, they all have a given utility level $\bar{u}$, which represents the total returns from their current assets. ${ }^{6}$ If a firm gets additional assets from the private sector, it expects to obtain a return $r$.This represents the ratio of the profits the firm expects from the assets to the cost of acquiring them. Thus, with restructuring, total utility for a firm is $\bar{u}+r$. We assume that different firms are characterized by different restructuring potentials $r$ so that $r$ is distributed with a strictly positive density $f$ on $\lfloor\underline{r}, \bar{r}\rfloor$, where $\underline{r}<0$ and $\bar{r}>0$. The distributional assumptions imply that there will be a set of firms for which the status quo is preferable to additional investment (those for which $r<0$ ). These can be interpreted as those firms which are so inefficient that profits obtained from new assets acquired at market price are not enough to compensate for the costs of acquiring

\footnotetext{
${ }^{4}$ According to Roland, strategic restructuring "refers to the objective of innovation and investment necessary to enhance enterprise performance” (2000, p. 234). This is the notion of restructuring we use here.

${ }^{5}$ If it is, then a measure of the extent to which a firm has acquired assets from SOEs as opposed to the private sector, may be correlated to asset stripping. How strong this correlation is, will then be an empirical question: in section 3, we will use the percentage of capital coming from SOEs as a proxy for a firm's degree of involvement in asset stripping and we will argue that there is evidence to suggest that this measure does indeed capture the phenomenon.

${ }^{6}$ That all firms share a common value $\bar{u}$ might seem a strong assumption. However, this simplifies our analysis considerably and our results are robust to more realistic assumptions about the
} 
the assets themselves.

Alternatively, the assets can be acquired from SOEs (asset stripping) and this generates different returns, which are captured by the continuously differentiable function $v(r)$, so that total utility with asset stripping is $\bar{u}+v(r)$. We assume (1) that the cost of acquiring the assets from the private sector is always greater than the cost of acquiring them through SOEs so that $v(r)$ is always greater than $r$, (2) that the cost of acquiring the assets with asset stripping is so low that even the most inefficient firm would want to utilize stripped assets $(v(\underline{r})>0)$, and (3) that $0<\frac{d v(r)}{d r}<1$.

As we will show in more detail below, the first two assumptions will imply that, absent law enforcement, asset stripping is always preferable to restructuring or even to the status quo. The last assumption, however, states that as firms become more efficient, gains from asset stripping increase but not as much as the gains from restructuring. The logic behind this assumption is that as the profitability of the assets increases, the state will have a greater incentive to invest in reducing both the control and informational gap with SOE insiders so that the opportunities for assets stripping reduce and/or the price differential between assets from SOEs and the private sector shrinks. This makes the returns from asset stripping closer to those from restructuring.

While asset stripping is the cheapest way to obtain assets, it is not without risks since the government can decide to act against it in order to avoid the consequent deadweight costs (these costs are discussed below). We assume that if a government decides to act and this is successful, the firm is left with zero utility, thus losing even its status quo utility $\bar{u}$. On the other hand, asset strippers can influence the government's decision to act. In particular, firms who intend to utilize stripped assets will provide the government with private benefits (e.g. bribes or political support), in exchange for its inaction.

In order to model these private benefits, we assume that each firm is also characterized by a parameter $s$, which is distributed independently of $r$ and with strictly positive density $g$ on $[0, \bar{s}]^{7}$. The parameter $s$, represents the size of the firm's current assets: the larger $s$ is, the greater the private benefits provided to the government so that these 
benefits are proportional (and, for simplicity, equal) to $s$. Two things are important to note here. The first is that to keep matters simple, we do not model the cost of providing these private benefits directly: the only assumption needed for our results is that even with them, the direct costs of asset stripping are lower than the costs of acquiring assets from the private sector so that returns for the former are higher than returns for the latter. The second is that we assume that $s$ (and not $r$ ) determines a firm's ability to provide private benefits because $r$ is a measure of returns on investment, not overall spending ability. A small firm could have a high value of $r$ because it is very efficient but be relatively incapable of providing significant bribes simply because it is small. A further reason for arguing that $s$ and not $r$ is the relevant variable here, is that as well as providing bigger direct monetary benefits, larger firms have more political clout because their fortunes impact more voters and this makes it more difficult for politicians to act against them. ${ }^{8}$

Following the recent literature in political economy (Grossman and Helpman, 2001), we assume that the government has both a "benevolent" and a "egoistic" side: on the one hand, the government seeks to maximize total efficiency in society, but on the other hand it also cares about the possible private benefits it may receive in exchange for inaction on asset stripping.

We model these assumptions by representing the government's objective function as $U_{G}=\alpha W+(1-\alpha) B$, where $W$ is equal to the returns on investment generated by firms in society and $B$ represents the overall private benefits the government receives. $\alpha \in[0,1]$ is a parameter that represents the trade-off between the government's concerns for public welfare and its own private welfare.

If the government decides to act against asset stripping, it must pay a per-firm cost of $c$ and it is effective only with probability (1-q). If it doesn't act, it faces a large deadweight cost because of the welfare losses associated with asset stripping. Amongst these losses is that stripped assets are generally not allocated to their most efficient user, that there will be a perception of a lack of protection of property rights (with negative consequences on investments), that the perceived lack of fairness in the process may make the whole

\footnotetext{
${ }^{7}$ In our dataset, the independence assumption is not rejected.

${ }^{8}$ See Shleifer and Vishny (1994) or Debande and Friebel (2004) for a similar assumption.
} 
transition unpopular, and the fact that the financial sector may be forced to take on too much risk. $^{9}$

We model the government's payoffs as follows: for any firm that does not use stripped assets, welfare returns to the government are equal to those of the firms themselves (thus, the government gets either $\bar{u}$ or $\bar{u}+r$ ) while private benefits are zero since there is no need to buy the government's acquiescence. ${ }^{10}$ Similarly, for any firm that does use stripped assets but is unsuccessful because the government acts and the firm is caught, we assume that the government optimally re-allocates the assets thus generating again returns equal to the case described above. Finally, to keep things as simple as possible, we assume that if the firm does use stripped assets and the government doesn't act or acts but cannot stop the stripping, the deadweight cost is such that welfare returns $W$ are zero. Private benefits (bribes or political support) occur only if the government didn't act in the first place.

The whole game is common knowledge to firms while the government cannot observe a firm's $r^{11}$ nor whether it has actually stripped assets or not. This implies that the government is aware of the size of a firm but it is not aware of its potential for restructuring or asset stripping and it doesn't know which firms have stripped assets and which haven't. ${ }^{12}$

Figure 1 summarizes payoffs for firms and for the government. We define the strategies available to firms as $\mathrm{N}$ (no change), R (restructure), and S (asset stripping) while A means that the government decides to act and -A that it decides not to take action.

\section{[INSERT FIGURE 1 ABOUT HERE]}

\footnotetext{
${ }^{9}$ If stripped assets end up in the informal economy or lead to capital flight, asset stripping implies other potentially significant costs.

${ }^{10}$ Obviously, there might still be private benefits from other sources but here we focus solely on the benefits provided by asset stripping firms in order to stop the government from acting in this specific regard.

${ }^{11}$ This is in accordance with the notion that SOE control is in the hands of managers who are the only ones who can judge how efficiently can a buyer firm use those assets.

${ }^{12}$ Alternatively, one could assume that while not able to determine a firm's precise $r$, the government can tell whether or not asset stripping has occurred simply by looking at whether or not the asset comes from SOEs. Thus, enforcement is not a problem of finding asset strippers but only a problem of convicting them. This assumes that different government branches (those in charge of SOEs and those in charge of law enforcement) can coordinate with each other, which is a strong assumption.
} 
The timing of the model is as follows. In the first stage, firms choose one of the three possibilities: $\mathrm{N}, \mathrm{R}$ or $\mathrm{S}$. In the second stage and upon observing $s$ for each firm, the government decides whether to act against the firm or not. Nature determines the success of the possible action against asset stripping and payoffs are realized.

To analyze the model, we proceed by backward induction and for simplicity will consider only equilibria in pure strategies. In the second stage, the government has to decide whether or not to act. This implies resolving a trade-off. On the one hand, acting will result in higher welfare because it reduces asset stripping. On the other, if it acts, it has to pay the cost of enforcements and will get no private benefits (e.g., bribes or political support). In addition, the government can observe $s$ but not $r$ so that it may form expectations as to whether the firm is an asset stripper but cannot know that for sure. Since private benefits are increasing in $s$ this implies that the government's strategy will be one where action will be chosen for all firms such that $s$ is no greater than some type $s^{*}$, while inaction will be chosen in the opposite case. Formally, we have:

Proposition 1 The government will decide to enforce the law if $s \leq \min \left(\bar{s}, s^{*}\right)$ while it will not act against any firm of size $s>\operatorname{Max}\left(0, s^{*}\right)$ where $s^{*}$ is the solution to

$$
\alpha E_{F}(W \mid A, s)+(1-\alpha) E_{F}(B \mid A, s)-c=\alpha E_{F}(W \mid-A, s)+(1-\alpha) E_{F}(B \mid-A, s)
$$

where $\mathrm{F}$ is the distribution function for $r, E_{F}(W \mid X, s)$ and $E_{F}(B \mid X, s)$ are the expected values of $W$ and $B$ conditional on $s$ and the government choosing strategy $X=A,-A$.

Note that $E_{F}(W \mid A, s)$ is independent of $s$ because returns do not depend on firm size. Also, $E_{F}(W \mid-A, s)$ equals zero because when government does not act, there will be asset stripping, while $E_{F}(B \mid A, s)$ is equal to zero because if the government acts it will not receive any private benefit. Finally, $E_{F}(B \mid-A, s)$ is equal to $s$ because these are the private benefits received in exchange for inaction. This means that equation (1) becomes

$$
\alpha E_{F}(W \mid A)-c=(1-\alpha) s
$$

Either way, our main results are not affected. 
where the left-hand side term is constant in $s$ while the right-hand side is an increasing function of $s$.

To determine $E_{F}(W \mid A)$ explicitly, consider the behavior of a firm manager when she has to decide whether to strip assets, do nothing or restructure. As mentioned, our assumptions imply that if there is no government action expected, asset stripping is a dominant strategy for all firms. If a firm expects government action, on the other hand, it will face the following choice. If it decides to strip assets, expected utility is $q(\bar{u}+v(r))$ : the probability that government action will be ineffective times the gains from asset stripping. If it decides to do nothing, her utility is $\bar{u}$. Finally, if it decides to restructure, utility is $\bar{u}+r$. Thus, asset stripping is the preferred option if $q(\bar{u}+v(r)) \geq \bar{u}+\operatorname{Max}(r, 0)^{13}$. Hence, we have two cases. In the first, firms are inefficient and asset stripping requires $q(\bar{u}+v(r)) \geq \bar{u}$, while in the second case, firms are efficient and asset stripping requires that $q(\bar{u}+v(r)) \geq \bar{u}+r$.

It is easy to see that our assumptions on the function $v(r)$ ensure that the first inequality determines a value $r_{A}=v^{-1}\left(\frac{1-q}{q} \bar{u}\right)$ such that asset stripping will occur for all firms such that $r>r_{A}$ while nothing will be done for the remaining firms. ${ }^{14}$ The interpretation is that some firms are so inefficient that additional assets obtained through asset stripping will not improve their performance enough to compensate for the risk of getting caught. It is also easy to see that our assumptions guarantee that $r_{A}$ is increasing in $\bar{u}$ as the opportunity cost of asset stripping increases and decreasing in $q$ because the probability of being caught decreases.

The second inequality (implicitly) determines a value $r_{B}>r_{A}$ such that asset stripping occurs for all efficient firms such that $r<r_{B}$, while the remaining efficient firms will restructure. So, the most efficient firms will not utilize stripped assets and will be restructured because these firms are so productive that high returns can be made without the

\footnotetext{
${ }^{13}$ We focus on equilibria where indifference between asset stripping and one of the other options is resolved in favor of the former.

${ }^{14}$ Both here and for the value $r_{B}$ below, we assume that the parameter restrictions necessary for $r_{A} \in[r, 0)$ and $r_{B} \in(0, \bar{r}]$ are satisfied.
} 
risks associated with asset stripping. Again, it is easy to see that $r_{B}$ is decreasing in $\bar{u}$ and increasing in $q$ for the same reasons described above.

Given this analysis, we have that (2) becomes

$$
\alpha\left[\bar{u}\left(1-q\left(F\left(r_{B}\right)-F\left(r_{A}\right)\right)\right)-q\left(r_{B} F\left(r_{B}\right)-\bar{F}\left(r_{B}\right)+\bar{F}(0)\right)+\Delta\right]-c=(1-\alpha) s
$$

where $\bar{F}$ is the left-integral of the distribution function $\mathrm{F}$ and $\Delta=\bar{r}+\bar{F}(0)-\bar{F}(\bar{r})$. This leads to:

Proposition 2 In equilibrium,

$$
s^{*}=\frac{\left.\alpha \bar{u}\left(1-q\left(F\left(r_{B}\right)-F\left(r_{A}\right)\right)\right)-q\left(r_{B} F\left(r_{B}\right)-\bar{F}\left(r_{B}\right)+\bar{F}(0)\right)+\Delta\right]-c}{1-\alpha}
$$

Further, firms will always strip assets if their size is above $s^{*}$. If their size is below $s^{*}$, firms will be partitioned in three categories according to their potential profitability: firms in $\left[r_{A}, r_{B}\right]$ will resort to asset stripping, firms in $\left[\underline{r}, r_{A}\right)$ will do nothing and firms in $\left(r_{B}, r\right]$ will restructure.

A corollary to the proposition above that follows from simple differentiation is:

Corollary 3 Assuming $s^{*} \in(0, \bar{s})$, we have that $s^{*}$

1. Is increasing in how much government cares for welfare as opposed to private benefits $(\alpha)$.

2. Is decreasing in the cost of government action (c).

3. Is increasing in the status quo value of firms' assets $(\bar{u})$.

4. Is decreasing in the probability of ineffectiveness of law enforcement $(q)$.

Figure 2 summarizes these results. A firm's potential returns are on the horizontal axis, while its size is on the vertical axis. 


\section{[INSERT FIGURE 2 ABOUT HERE]}

The figure shows how governments partition firms in two categories: those for whom action is worthwhile (firms in II, III and IV) and those for whom it isn't (firms in I). In region I there is no action, managers will always use stripped assets and government only gets private benefits. In regions II, III and IV government acts so that no private benefits are accruing to it but action does stop some firms from using stripped assets: in region II firms do nothing (these firms are all inefficient) and in region IV firms will restructure. In both cases, there are public benefits to the government. In region III, all firms use stripped assets even with government action. However, if these firms are caught, the government will reclaim the assets and allocate them optimally.

The intuition for this pattern is that the government trades off the public benefits of action against the private benefits obtained if there is no action. This trade off is directly affected by changes in the parameters $\alpha$ and $c$ : if $\alpha$ increases (i.e., the government is less interested in private benefits), the difference in returns between I versus II, III and IV changes in favor of the latter. Given that, it is optimal for the government to act against larger firms. Conversely, if $c$ (the cost of law enforcement) increases, net returns for the government stay the same, but now action has become more expensive so that there is an incentive for the government to reduce the maximum size of firms for which it will enforce the law. The intuition from the firm point of view is that there will be three types of firms below $s^{*}$. On one extreme, there are firms that are so inefficient that it is not worthwhile for them either to restructure or to take on the law enforcement risks associated the use of stripped assets. On the other extreme, we have highly efficient firms for which there is no need to use stripped assets because potential profitability through restructuring is high vis-àvis the risk of getting caught using stripped assets. It is the remaining firms (those with intermediate levels of efficiency and sufficient clout) that will strip assets.

While the first two parameters directly influence the government's preferences, $\bar{u}$ and $q$ influence its decision to act indirectly, through firms' behavior. Any increase in $\bar{u}$ (which could be interpreted as a measure of the average efficiency in the economy) will increase the opportunity cost of stripping assets for any firm facing action from the government. Thus, when government takes action, fewer firms strip assets, increasing the government's returns which leads to government action against a larger section of firms, 
increasing $s^{*}$. An increase in $q$, (action becomes less effective) provides the opposite effect since now, the opportunity cost of asset stripping decreases.

To conclude, this section has provided a simple theoretical framework for the analysis of firms' decisions with regard to asset stripping and government's decision to act against it or not. The two main testable empirical implications from our model are:

(a) Governments will be more willing to act against small firms because these cannot have the same level of political influence as large firms. This means that large firms have more incentives to strip assets than small firms.

(b) For those firms that do face law enforcement, we expect asset stripping to be more frequent if they are at an intermediate level of potential profitability. Jointly with (a), this means that the relationship is non-linear.

\section{DATA}

We use the data set put together by Johnson, McMillan and Woodruff (2002) to test the main implications of our model of asset stripping in transition economies. The survey was carried out in 1997 through face-to-face interviews with owners, CEOs or general managers of about 300 firms in five transition economies (Poland, Slovakia, Romania, Ukraine and Russia). Most of these were founded after 1990 and Johnson et al. (2002) argue that "the resulting sample is reasonably representative of small and medium-sized manufacturing firms in each country, though it is not a census" (p. 45). ${ }^{15}$

The data set has a few disadvantages we should mention at the outset. One likely drawback is that the data were collected with different purposes, to capture contractual

\footnotetext{
${ }^{15}$ According to Johnson, McMillan and Woodruff (2002), "In order to increase the cross-country comparability of the sample, the initial selection was limited to one medium-sized city in each country: Katowice (Poland), Brasov (Romania), Bratislava (Slovakia), Volgograd (Russia) and Dnepopetrovsk (Ukraine). Only in Slovakia did we have trouble identifying a large enough sample of firms meeting our size criteria who were willing to participate. In the final sample, about one-quarter of the Slovakian firms are located in Bratislava, one-quarter in Kosice, and the remaining half are spread across seven other cities. Participation was high among the firms contacted -in excess of $70 \%$ in Poland and Romania, and 68\% in Slovakia.”
} 
relations between the firm and its suppliers and customers. Therefore the set of variables of potential interest for a study of asset stripping is limited. Another disadvantage is that the survey is limited to a single year, with no time series aspect to it. A third possible disadvantage is that firms from only five transition economies were interviewed. Finally, the sample does not include firms with large number of employees. This makes it harder to capture some factors that may impact on a firms' ability to exercise influence over law enforcement, such as the political connections that managers may have or the fact that the firm has so many employees-voters that government is reluctant to act against it. However, there are other means of influence such as bribes which are available to small and medium sized firms and yet in a degree proportional to their size. Because this data set cannot capture the full variety of ways of influencing public officials that large firms may have, we expect any results that support our theory to be conservative estimates of the true relationship between firm size and asset stripping.

We believe that the advantages outweigh the disadvantages. One important advantage is that, although cross-sectional, the survey was carried out in 1997. This was a year close enough to the beginning of the transition so that managers and owners remembered how much of their capital came from state-owned enterprises. Yet 1997 was also far enough from the beginning of the transition that most asset stripping would be over and owners and managers would not be as reluctant to disclose its extent. Another important advantage is that although the survey does not cover all transition economies, the group of five countries displays a useful array of speeds and types of institutional and economic reform and initial conditions. ${ }^{16} \mathrm{~A}$ third positive feature is that the survey encompasses firms from different manufacturing sectors (namely, metal products, wood, food, clothing, construction, chemical, pulp and paper, handicrafts, and electric equipment), allowing us to control for potentially crucial sectoral differences, including capital intensity. And a fourth positive feature regards the relatively large number of firms from each country. This allows us enough degrees of freedom to be able, for instance, to discard from the sample those firms that were previously parts of state-owned enterprises (spin-off firms) since capital

\footnotetext{
${ }^{16}$ For instance, in terms of progress in transition the EBRD (1999) indicators place Poland as a top all-around performer and Slovakia as a good performer with caveats in terms of accountability and transparency. Romania is classified as an intermediate case, while Russia and Ukraine, in this order, complete the ranking.
} 
from state enterprises is, almost by definition, more likely to be found in a spin-off than in a start-up firm.

Thus, in order to provide estimates of asset stripping that are conservative, we limit our attention to start-up firms and we do that by keeping in the sample only those firms that answer "no" to the question "was this firm previously a part of a state enterprise?" We start out with slightly less than 1,500 firms in the five countries and once we restrict it to those firms that were not previously part of a state-owned firm, the sample reduces to 966 firms: 237 in Poland, 238 in Slovakia, 281 in Romania, 128 in Ukraine and 82 in Russia. ${ }^{17}$

The measure of asset stripping we propose is the percentage of the firm's capital equipment obtained from a state enterprise. We refer to physical capital currently owned by a start-up firm that originated from a state-owned enterprise. In the survey, the question is phrased as follows: "How much of your capital equipment came from state enterprises which helped found this firm?” The respondent is asked to indicate whether the answer to this question is $0 \%, 1-25 \%, 26-50 \%, 51-75 \%$ or $76-100 \%$. Notice that the question is restricted to capital equipment and excludes profits, buildings, brands, patents and land, which are assets that might also have been subject to stripping.

Admittedly, one important problem with this measure is the possibility that not all capital from SOEs in a start-up firm was acquired through asset stripping, as we defined it. It may well be the case that the firm obtained those assets at their market value and not through inside deals with managers, bureaucrats or politicians. Our response to this objection is twofold.

Firstly, the empirical analysis will show that with this measure we get results that are compatible with the theory but cannot be easily explained if the measure simply reflected the choice between capital from former SOEs and capital from the private sector. In particular, there is strong evidence for a non-linear relationship between a firm's profitability and this measure. If the measure did not capture asset stripping, it would be difficult to understand why such a relationship would obtain. In other words, why would firms with intermediate

\footnotetext{
${ }^{17}$ It must be noted that all econometric results presented in this paper are, not surprisingly, even stronger when we use the full sample (that is, start-up as well as spin-off firms). These are available from the authors upon request.
} 
levels of profitability choose to use a higher percentage of capital from SOEs than very profitable or very unprofitable firms?

Secondly, we find large differences across countries in terms of our index. Table 1 shows that the percentage of start-up firms that say that a positive share of their initial capital stock came from the state sector is much greater in Russia and Ukraine than elsewhere. The index strongly suggests this share is much larger in Russia and Ukraine than in Poland, Slovakia and Romania. ${ }^{18}$

[INSERT TABLE 1 ABOUT HERE]

This ranking in terms of our index maps quite well with country rankings based on government corruption and performance in transition (Treisman, 2003.) This is what we should expect according to our theory, as these are precisely the factors that should increase SOE insiders' control and informational advantages, which make asset stripping easier. What else can explain these country-level differences and still be compatible with the notion that little or no asset stripping is being captured by our index? One possibility is that there are differences in privatization strategies, which could account for the different distribution of former state assets in the start-ups of the different countries. This is unlikely to be the case. In terms of the actual amount of privatization that occurred, by 1997 the private sector share in GDP was 55\% for Ukraine, $60 \%$ for Romania, $65 \%$ for Poland, $70 \%$ for Russia and $75 \%$ for Slovakia (EBRD 1999): this is at odds with the notion that the larger share of capital from SOEs in Ukrainian firms is due to the fact that Ukraine privatized more. Further, the cross-country aspect of the data is useful because these five countries have employed different privatization methods. Among the countries in our sample, Russia and Slovakia used voucher schemes extensively in their privatization processes, while Romania and Ukraine emphasized privatization to insiders (management buyouts). This contrasts with the possibility that the similarity in the index between Russia and Ukraine, on the one hand, and Romania and Slovakia, on the other, is due purely to the privatization method involved.

\footnotetext{
${ }^{18}$ Not surprisingly, the percentage of firms that answer "zero" is substantially smaller if we consider start-ups and spin-offs: $81 \%$ for Poland (down from 95\%), 79\% for Slovakia (down from 96\%), $76 \%$ for Romania (down from 87\%), 33\% for Ukraine (down from 62\%) and 19\% for Russia (down from 64\%).
} 
A second possible problem with our measure relates to the sectoral distribution of economic activity across countries. If it was the case that firms in sectors with more SOE capital all belonged to certain countries (in particular, Russia and Ukraine), then we could not be confident that our index reflects actual stripping of assets. All the transfer of assets from state firms to the start-ups in our sample could have been done without asset stripping and the differences across countries explained simply by the different sectoral compositions in the sample. This is not the case. The econometric evidence presented below shows that we do not find statically significant differences in explaining asset stripping by country across sectors.

This does not necessarily mean that sectoral differences in themselves are not important. Table 2 shows the distribution of asset stripping across industrial sectors, irrespective of country of operation. One way of reading the table is to try to identify those sectors with the lowest share of firms saying that zero percent of their capital came from state enterprises (those will be the sectors with relatively more asset stripping according to our measure). From Table 2, we identify handicrafts, wood and food products and clothing as the sectors in which asset stripping is relatively low. On the other hand, asset stripping seems relatively high in metal parts, construction, chemical products, electrical machinery and in pulp and paper.

\section{[INSERT TABLE 2 ABOUT HERE]}

\section{EMPIRICAL RESULTS}

The theoretical model presented above generates two main testable hypotheses. One is that firm size (as a proxy for the firm's political clout or ability to bribe) is an important determinant of asset stripping in transition economies. The other is that there is a non-linear relationship between the extent of the use of stripped assets and potential profitability. In this section, we investigate whether our data provides support for these two main hypotheses.

We focus our analysis on the probability of using stripped assets. ${ }^{19}$ In order to do that, we recode the original variable to take values of 1 if the share of capital from former

\footnotetext{
${ }^{19}$ One may expect that the percentage of stripped assets on total initial capital equipment is more important than the decision of whether or not to use stripped assets. There are no qualitative changes in the results if ordered probit estimation is applied instead. These results are available from the authors upon request.
} 
SOEs is positive, and zero otherwise. Table 3 presents maximum-likelihood probit estimates for our measure of asset stripping. Column 1 shows our results when we control for country and industry-specific characteristics. It shows that size, as measured by total number of employees at the date the firm was founded, is a positive and statistically significant determinant of asset stripping, as our model predicts. The coefficient implies that, at the mean, an increase of one unit in the size of the firm (that is, one additional employee) leads to an increase in the probability of using stripped assets of 0.04 percentage points. ${ }^{20}$ There are some other important results with respect to the fixed effects. Romania was chosen as the reference category for the countries and "miscellaneous" as the reference category for the industrial sectors. According to our measure of asset stripping, once again it seems to be a more severe problem in Russia and Ukraine than in Poland and Slovakia. In terms of the industrial sectors, the results are less informative. Yet, there is evidence suggesting that asset stripping is less severe in the food and handicrafts industries. ${ }^{21}$ These sector specific fixed effects help to minimize the risk that our results are driven by the different capital intensities of the average firm in different sectors.

\section{[INSERT TABLE 3 ABOUT HERE]}

One potential problem with these results is that the variable capturing firm size includes part-time workers. The data set offers an alternative, namely the number of fulltime workers at the date the firm was founded. Column 2 shows our results if we use this different measure of firm size. We again find that larger firms seem to have more stripped assets from state-owned enterprises. Notice that using a measure of firm size at the date the firm started to operate helps to address endogeneity concerns. Further, the pattern of results with respect to the country dummies does not change. As for differences across industries, one change is that using full-time workers as a measure of size, the clothing sector also

\footnotetext{
${ }^{20}$ Note that if we include spin-off firms in our sample, the coefficient on firm size implies that an increase in firm size of one employee leads to an increase in the probability of using stripped assets of 0.3 percentage points (vis-à-vis 0.04 ).

${ }^{21}$ In principle, it is possible that different sectors in different countries are systematically more (or less) prone to have stripped assets. In order to account for this, we tried adding interaction terms between our country and sector dummies to these specifications. There are no qualitative changes in
} 
appears to have been subjected to less asset stripping. Once again, country specific factors seem more important than sectoral effects in explaining asset stripping in transition.

A third important issue for our understanding of asset stripping in transition is the age of each firm. It is important to make sure that these results are not driven by differences in how long these private firms have been in operation (e.g., latecomers or newer firms having less access to capital from state-owned enterprises). Column 3 presents these results when controlling for the year the firm was registered and our preferred measure of firm size (number of full-time employees). The results change very little and ability to influence law enforcement as measured by firm size is still an important determinant. ${ }^{22}$ Further, the pattern of results obtained with the country and sector dummies remains. Column 4 shows that using another measure of age, namely the year when the firm started operating, generates similar results.

One important question is whether any potential omitted variable affect these results. One might expect that other factors would influence the propensity to strip assets, such as personal characteristics and occupational history of the firm's CEO, the firm's access to credit and the expectations about legal institutions that govern its behavior. It is important, therefore, to test whether the inclusion of such variables would affect our results. Column 5 reports the results when measures of such factors are included. Firstly, we look at whether or not the manager had previous public sector experience. We conjecture that such experience would provide knowledge and connections that would facilitate the stripping of assets. As can be seen in Column 5, the coefficient has the positive sign we expect, but it is not statistically significant. $^{23}$

Column 5 in Table 3 also shows how our results change when we take into account the issue of firms' access to credit. Specifically, we consider whether our firms received

our results.

${ }^{22}$ The coefficient implies that, at the mean, an increase of one unit in the size of the firm leads to an increase in the probability of using stripped assets of 0.04 percentage points.

${ }^{23}$ We have also tried managers' age, years of formal education and whether they have been highlevel managers before. We find that the coefficients on age and years of education were both statistically significant. Older managers were more likely to use stripped assets, as well as those with lower levels of formal schooling. Previous occupation, however, had no significant effect. More importantly, we repeated this exercise for all the specifications in this paper and our results continue to hold. 
start-up financing from state owned enterprises. Perhaps not surprisingly, those firms that received credit from this source are found to have a higher propensity to use stripped assets. $^{24}$ The coefficient is positive and statistically significant at the 10 percent level, and implies that having received start-up funding from a SOE increase the probability of using stripped assets by 6 percentage points. Finally, in Column 5 we also investigate the effect of expectations about legal institutions. More specifically, we ask whether the fact that a manager claims that firms in his or her industry pay for the "protection” of their activities increases the propensity to strip assets. ${ }^{25}$ We conjecture that firms that operate in an environment where such protection is needed are likely to face less effective law enforcement as well as government with higher propensity to accept bribes. Indeed, we find the coefficient on "protection" payments to be positive and statistically significant, and it implies that such payments increase the probability of using stripped assets by 10.4 percentage points. $^{26}$ The most important point, however, is that with all these controls, size remains a significant factor in explaining asset stripping.

The data set offers some additional measures of institutional effectiveness reflecting these differences. For instance, the survey asks firms to estimate the average share of unreported sales in total sales in their sector of activity. Table 4 exhibits these results, using the preferred measures of firm size and firm age (number of full-time employees at start of operation and year of start of operation, respectively). ${ }^{27}$ Column 1 shows that size is still an important determinant, although the coefficient on the institutional variable (share of

\footnotetext{
${ }^{24}$ We also investigated whether other sources of finance had an impact. Specifically, we looked at whether or not financing was obtained from own funds, from family and friends, from other private firms, from banks, and from issuing shares. Also we examined the composition of start-up financing by examining the effect of the share of each of these sources on overall finance. None of these coefficients were found to be statistically significant. Again, we repeated this exercise for all the specifications in this paper and our results remain.

${ }^{25}$ We also studied whether the amount of time spent by the manager dealing with government bureaucracy (as opposed to internal and external affairs) affects the propensity to strip assets. We find that this coefficient is statistically significant and positive as expected. Once more, we repeated this exercise for all the specifications in this paper and our results remain.

${ }^{26}$ Notice that these latter two variables are binary so these estimates are presented as the discrete change in probability of going all the way from zero to one (as opposed to a continuous small change as in the case of firm size).

${ }^{27}$ Note that we exclude country dummies because of severe multicollinearity between these and the institutional variables.
} 
unreported sales on total sales) is not statistically significant. ${ }^{28}$ Column 2 from Table 4 has similar results for another proxy for institutional conditions, the share of unreported salaries in total salaries. Although the major predictions from our model are borne out by the data, these results suggest an apparently counter-intuitive result for this institutional variable: the larger the relative share of unreported salaries, the smaller is asset stripping. One possible explanation is substitution: firms that cannot use stripped assets try to under-report their labor costs. Column 3 shows our results when the institutional variable is the share of input costs that are unreported. Note that the coefficient on institutions carries the expected sign: the higher the degree of underreporting (input costs in this case) the more likely the firm has looted assets. Column 4 shows the results for using the share of unreported exports in total exports and column 5 shows the same set of results when the institutional variable is the share of unreported imports in total imports. For these last two cases, although the coefficients on these institutional variables have the expected positive signs, only the one on exports is statistically significant. This coefficient implies that, at the mean, a one percent increase in the share of unreported exports, increase the probability of using stripped assets by 0.09 percentage points. Column 6 shows the effects of the share of time the manager spends dealing with government bureaucracy and regulations (as opposed to the firms' internal and external affairs). This coefficient is positive and statistically significant. Similarly to the analysis of the previous table, we emphasize that firm size is still an important explanatory factor (in a more complicated way than previously thought) in understanding asset stripping in transition. ${ }^{29}$

\section{[INSERT TABLE 4 ABOUT HERE]}

\footnotetext{
${ }^{28}$ Notice that the number of observations is considerably smaller than before and this is caused by the much higher number of firms that did not answer the institutional questions that are the focus of Table 4. One potential concern is that the smaller number of observations would influence the main results reported in Table 3. Thus, we re-run all specifications in Table 3 only for those firms that did actually answer these institutional questions. We find that there is no effect of the smaller number of observations on our results.

${ }^{29}$ One can argue that the joint effect of firm size and the institutions that determine the effectiveness of law enforcement has to be taken into account. We re-estimated these specifications adding interaction terms between firm size and the relevant institutional variable. Although the interaction terms were never statistically significant, our main results remained.
} 
Table 5 tests one of the main implications of the model. Recall that, in terms of efficiency, we predict there will be three types of firms. We first have firms with very low (relative) efficiency. For these, the expected payoff is so low that asset stripping does not occur. For the (relatively) highly efficient firms, there is no need to use stripped assets: potential returns are so high that the risk of getting caught is not worth taking. The third type of firm has intermediate levels of efficiency and is willing to use stripped assets, even if it risks being caught. Empirically this hypothesis translates into testing whether there is an inverted-U relationship between efficiency and asset stripping. One available measure of this relative efficiency, at the moment the firm was founded, is profitability. Column 1 shows that the share of after-tax profits over total investment in the first full year of operation of the firm has a positive and significant impact on asset stripping (notice that this result obtains irrespective of whether or not we control for the age of the firm). It is important to emphasize that these are not raw profits, but a measure of returns on investment along the lines suggested by our model. Column 2 shows that there is support in the data for the inverted-U theoretical prediction: the coefficient on the linear term is positive and statistically significant while the coefficient on the quadratic term is negative and statistically significant. Our main results are in Columns 3 and 4: the size of the firm is still a fundamental determinant of asset stripping in transition even when accounting for non-linear differences in firm profitability. ${ }^{30}$ Column 4 shows these results change little when we include controls for manager occupational history, payments for "protection” and start-up financing from SOEs. Our results remain and, again, the effects of payments for "protection” and start-up financing from SOEs are statistically significant.

\section{[INSERT TABLE 5 ABOUT HERE]}

\footnotetext{
${ }^{30}$ These results are also robust to the presence of a privatization variable that takes the value of 1 if "direct sales" was the primary or secondary method of privatization. These results are available from the authors upon request. These data are from Garibaldi et al. (2002), who construct three indicator variables ranking primary, secondary and tertiary privatization methods in all transition economies, yearly between 1990 and 1999. They consider three privatization methods: direct sales, vouchers and management-employee buyouts. Garibaldi et al. show that up to 1997, "direct sales” was never the primary method in any of our five countries. Further, up to 1997, "direct sales" was never the primary nor secondary method in Poland nor Ukraine. It was the secondary method for Russia after 1995, for Slovakia after 1992 and for Romania after 1993 (with the exception of 1996).
} 
A final important issue is the direction of causality: do large firms do more asset stripping, as we suggest, or do firms that use stripped assets grow faster? Unfortunately, the data lacks the time series aspect needed for a comprehensive test of this possibility. There is however an indirect way of testing this, namely by examining the effects of the use of stripped assets on firm growth. Table 6 has these results. Column 1 shows that, although firm growth does not seem different across sectors, it certainly differs across countries. Polish and Slovak firms seem to have grown much faster than their Romanian, Ukrainian and Russian counterparts. Second, the initial size of the firm matters for its subsequent growth: the smaller the firm, the faster it seems to have grown. Third, older firms seem to have grown faster than newer firms (notice that more than $60 \%$ of the firms in our sample start to operate between 1991 and 1994.) Column 2 adds our measure of asset stripping to this specification: the results just discussed remain. In addition, asset stripping has a positive effect on firm growth, although the coefficient is not statistically significant. Column 3 shows this result changes very little when we include controls for manager occupational history, payments for "protection" and start-up financing from SOEs. The fact that the coefficient on asset stripping is not significant suggests that causality runs in the direction we propose.

\section{[INSERT TABLE 6 ABOUT HERE]}

In summary, this section presented econometric evidence supporting the theoretical model. Specifically, the results seem to provide support for the two hypotheses. One is that firm size is an important determinant of asset stripping in transition economies: larger firms use more stripped assets. Another is that there is a non-monotonic relationship between profitability and asset stripping. These conclusions are robust to different proxies for institutional conditions, different estimators, differences in privatization methods, different sources of start-up financing, different managerial occupational histories, different ways of measuring firm size and different ways of measuring the age of the firm. 


\section{CONCLUSIONS}

In this paper, we present a simple model of asset stripping in transition economies, which highlights the importance of political power and potential profitability. The model rests on the assumption that due to differences in the state's ability to exercise control and obtain information, asset stripping is inherently easier if assets from SOEs are involved. We argued that relatively large firms, which use stripped assets, will be safe from law enforcement because governments understand that the costs of intervening against them (in terms of influence, bribes or political support) are larger than the benefits of reclaiming the stripped assets.

Using firm-level survey data for about 950 firms in Poland, Slovak Republic, Romania, Ukraine and Russia in 1997, we find strong support for the two main theoretical implications from the model. A first important result is firm size turns out to be an important determinant of asset stripping in transition economies (and it does so in more complicated ways than previously thought.) This result is robust to different proxies for institutional conditions, different ways of measuring firm size, different ways of measuring the age of the firm and to the use of different estimators. A second important result is the finding of a nonlinear relationship between potential profitability and use of stripped assets: we find that those firms with sufficient political power and intermediate levels of potential profitability will be the ones that choose to use stripped assets.

This is one of the first papers to provide a theoretical explanation of asset stripping in the transition from communism followed by supporting econometric evidence. It is natural thus that there are a number of suggestions for future research. One is that we offer a tractable model of asset stripping that is essentially static. It would be interesting to see whether a dynamic framework would generate strikingly different conclusions. Although we suspect that it would not in our case, we think that it would alter some findings in the literature, for instance, the notion that it is in the interest of the politically powerful social groups to have very imperfectly defined property rights. Although there is a clear rationale for such a situation at the outset, that is before assets change ownership, we believe that that will not be the case later on (after the ownership of assets has changed and the risk of expropriation is low.) 
Perhaps more importantly, we believe these results provide lessons for privatization that not are restricted to transition economies. As noted, the basic assumptions of our theory, that SOEs have weaker corporate governance and that public officials are vulnerable to influence from asset strippers hold true for many developing economies as well. The first observation that follows from our analysis is that the decision to privatize, or to recommend privatization, should take into account the potential costs of asset stripping whenever corporate oversight is weak and political incentives are unreliable. These costs can be substantial: as discussed above, our results are likely to have underestimated asset stripping and yet we have that an additional hundred employees increase the probability that the firm will use stripped assets by four percentage points. On the other hand, our results also allow policy makers to understand the specific cases, depending on the size of the firms involved and their profitability, in which asset stripping is more likely to happen.

Thus, while our work has focused on transition economies, future work might focus on other developing countries in order to assess the generality of our theory. This could also address some weaknesses in our analysis, by exploring other forms of asset stripping, for instance, stripping that relate to other assets (such as buildings and infrastructure) and to intangibles (for example, brand names). Future research might also try to provide a better understanding of the connections between asset stripping and capital flight. 


\section{BIBLIOGRAPHY}

Akerlof, G. and P. Romer (1993), “Asset Stripping: The Economic Underworld of Bankruptcy for Profit.” Brookings Papers on Economic Activity 2: 1-60

Black, B., R. Kraakman and A. Tarassova (2000), "Russian Privatization and Corporate Governance: What Went Wrong.” Stanford Law Review 52: 1731-1808.

Blanchard, O. and M. Kremer (1997), “Disorganization.” Quarterly Journal of Economics 112 (4): 1091-1126.

Campos, N. and F. Coricelli (2002), "Growth in Transition: What We Know, What We Don’t, and What We Should,” Journal of Economic Literature, 40 (3): 793-836.

Cull, R., Matesova, J. and Shirley, M. (2002), “Ownership and the Temptation to Loot: Evidence from Privatized Firms in the Czech Republic.” Journal of Comparative Economics 30: 1-24.

Debande, O. and Friebel, G. (2004), “A Positive Theory of 'Give Away’ Privatization,” International Journal of Industrial Organization, 22 (8-9): 1309-1325.

EBRD (1999), Transition Report, EBRD.

Freeland, C. (2000), Sale of the Century: Russia's Wild Ride from Communism to Capitalism, Times Books.

Ganev, Venelin (2001), “The Dorian Grey Effect: Winners and State Breakers in Postcommunism,” Communist and Postcommunist Studies, 34: 1-25.

Garibaldi, Pietro, Mora, Nada, Sahay, Ratna, Zettelmeyer, Jeromin (2001), "What Moves Capital to Transition Economies?” IMF Staff Papers 48: 109-145.

Goldman, M. (2003), The Privatization of Russia: Russian Reform Goes Awry, Routledge.

Grossman, G. and E. Helpman (2001), Special Interest Politics, MIT Press.

Hoff, K. and Stiglitz, J. (2004), “After the Big Bang? Obstacles to the Emergence of the Rule of Law in Post-Communist Societies". American Economic Review, 94(3): 753-763.

Johnson, S., McMillan, J. and Woodruff, C. (2002), "Property Rights and Finance.” American Economic Review 92 (5): 1335-1356.

Johnson, S., La Porta, R., Lopez-de Silanes, F. and Shleifer, A. (2000), “Tunneling.” American Economic Review, 90 (2): 22-27.

Rodrik, D. (1996), “Understanding Economic Policy Reform,” Journal of Economic Literature 34 (1): 9-41. 
Roland, G. (2000), Transition Economics: Politics, Markets and Firms, MIT Press.

Roland, G. and Verdier, T. (2003), “Law Enforcement and Transition,” European Economic Review 47: 669-685.

Shleifer, A. and Vishny R.W. (1994), "Politicians and Firms.” Quarterly Journal of Economics, 109: 995-1025.

Sonin, K., (2003), "Why the Rich May Favor Poor Protection of Property Rights,” Journal of Comparative Economics, 31 (4), 715-731.

Stiglitz, J. (2000), “Whither Reform? Ten Years of the Transition.” Mimeo, World Bank.

Tornell, A. and P. Lane (1999), “The Voracity Effect,” American Economic Review, 89 (2): 22-46.

Treisman, D. (2003), “Post-Communist Corruption” in N. Campos and J. Fidrmuc (eds) Political Economy of Transition and Development: Institutions, Policies and Politics, Kluwer, Boston/London. 


\section{Figure 1}

Returns to firms and returns to government

\begin{tabular}{|l|l|l|}
\hline & Returns to firms & Returns to government \\
\hline $\mathrm{N}$ & $\bar{u}$ & $\alpha \bar{u}$ \\
\hline $\mathrm{R}$ & $\bar{u}+r$ & $\alpha(\bar{u}+r)$ \\
\hline $\mathrm{S}-$ unsuccessful & 0 & $\alpha(\bar{u}+\max (r, 0))$ \\
\hline $\mathrm{S}-$ successful and A & $\bar{u}+v(r)$ & 0 \\
\hline S - successful and $-\mathrm{A}$ & $\bar{u}+v(r)$ & $(1-\alpha) s$ \\
\hline
\end{tabular}


Figure 2

Equilibrium behavior

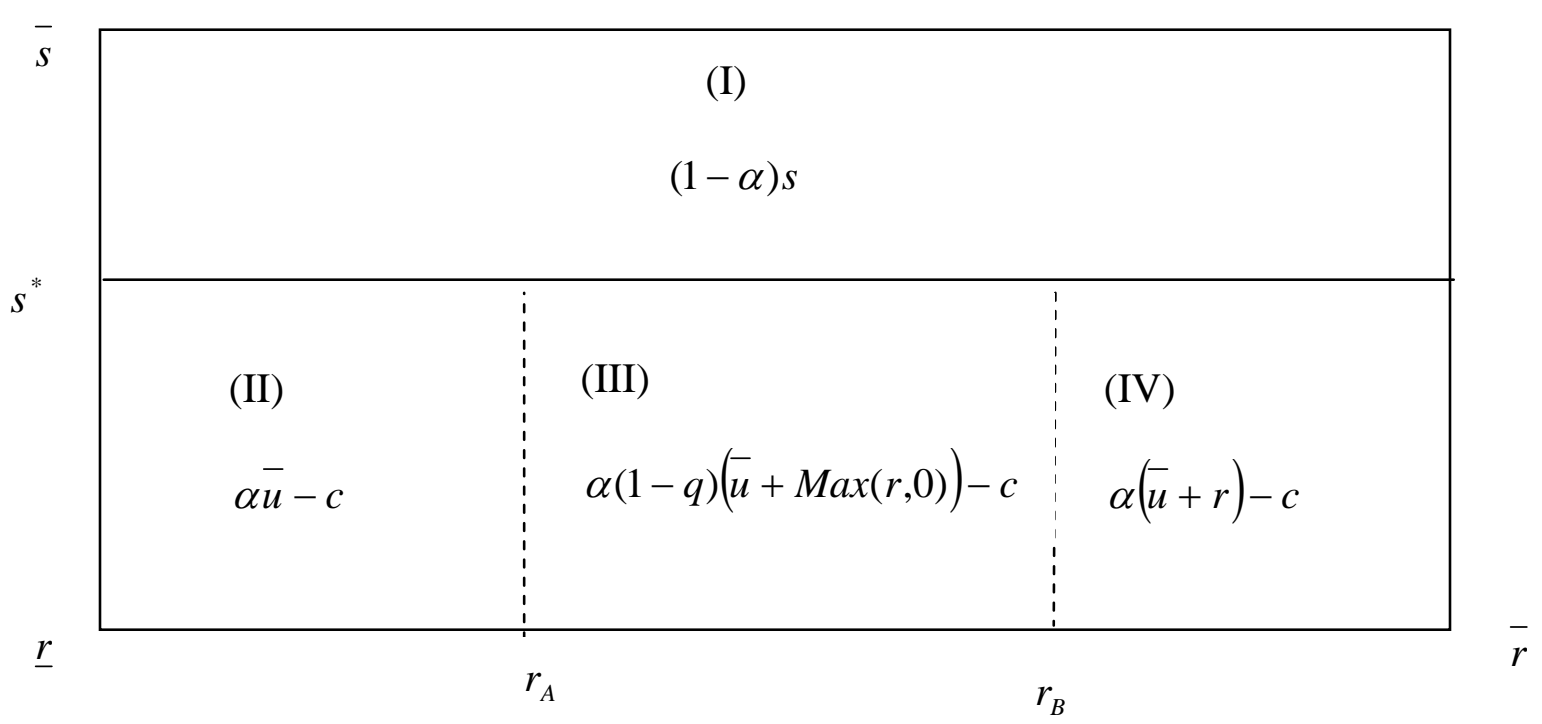




\section{Table 1}

The Extent of Asset Stripping Across Selected Transition Economies (1997)

\begin{tabular}{|l|l|l|l|l|l|}
\hline Country & $0 \%$ & $1-25 \%$ & $26-50 \%$ & $51-100 \%$ & Total \\
\hline Poland & 95.76 & 2.97 & 0.00 & 1.27 & 100.00 \\
\hline Slovakia & 96.22 & 0.84 & 1.26 & 1.68 & 100.00 \\
\hline Romania & 87.19 & 9.25 & 2.14 & 1.42 & 100.00 \\
\hline Ukraine & 62.99 & 15.75 & 18.90 & 2.36 & 100.00 \\
\hline Russia & 64.20 & 25.93 & 8.64 & 1.23 & 100.00 \\
\hline Total & 86.40 & 7.89 & 4.15 & 1.55 & 100.00 \\
\hline
\end{tabular}

Note: The figure refers to the percentage of answers in the category.

Source: Authors' calculation. 


\begin{tabular}{|c|c|c|c|c|c|}
\hline \multicolumn{6}{|c|}{$\begin{array}{l}\text { Table } 2 \\
\text { The Extent of Asset Stripping Across Industrial Sectors (1997) }\end{array}$} \\
\hline $\begin{array}{l}\text { Main Business } \\
\text { Activity }\end{array}$ & $0 \%$ & $1-25 \%$ & $26-50 \%$ & $51-100 \%$ & Total \\
\hline Metal Parts & 87.01 & 7.36 & 3.90 & 1.73 & 100.00 \\
\hline Wood & 92.00 & 5.33 & 1.33 & 1.33 & 100.00 \\
\hline Food & 91.41 & 3.91 & 3.13 & 3.56 & 100.00 \\
\hline Clothing & 94.08 & 3.29 & 0.66 & 1.97 & 100.00 \\
\hline Construction & 77.01 & 16.09 & 5.75 & 1.15 & 100.00 \\
\hline Chemical & 88.46 & 7.69 & 1.28 & 2.56 & 100.00 \\
\hline Paper & 76.67 & 10.00 & 10.00 & 3.33 & 100.00 \\
\hline Handicrafts & 93.33 & 6.67 & 0.00 & 0.00 & 100.00 \\
\hline Electric & 86.44 & 5.08 & 8.47 & 0.00 & 100.00 \\
\hline Miscellaneous & 72.22 & 16.67 & 10.19 & 0.93 & 100.00 \\
\hline Total & 86.40 & 7.89 & 4.15 & 1.55 & 100.00 \\
\hline
\end{tabular}




\begin{tabular}{|c|c|c|c|c|c|}
\hline & (1) & (2) & (3) & (4) & (5) \\
\hline \multirow[t]{2}{*}{ Firm size (all employees) } & 0.003 & & & & \\
\hline & {$[0.001]^{* * *}$} & & & & \\
\hline \multicolumn{2}{|l|}{ Firm size (full time employees) } & 0.003 & 0.003 & 0.003 & 0.003 \\
\hline & & {$[0.001]^{* * *}$} & {$[0.001]^{* * *}$} & {$[0.001]^{* * *}$} & {$[0.001]^{* * *}$} \\
\hline \multirow[t]{2}{*}{ Year firm registered } & & & -0.012 & & \\
\hline & & & [0.009] & & \\
\hline \multirow[t]{2}{*}{ Year firm started operation } & & & & -0.006 & -0.007 \\
\hline & & & & {$[0.010]$} & {$[0.010]$} \\
\hline \multirow[t]{2}{*}{ Dummy: Poland } & -0.636 & -0.62 & -0.678 & -0.649 & -0.675 \\
\hline & {$[0.175]^{* * *}$} & {$[0.176]^{* * *}$} & {$[0.186]^{* * *}$} & {$[0.184]^{* * *}$} & {$[0.198]^{* * *}$} \\
\hline \multirow[t]{2}{*}{ Dummy: Slovakia } & -0.655 & -0.653 & -0.646 & -0.651 & -0.685 \\
\hline & {$[0.191]^{* * *}$} & {$[0.192]^{* * *}$} & {$[0.191]^{* * *}$} & {$[0.191]^{* * *}$} & {$[0.213]^{* * *}$} \\
\hline \multirow[t]{2}{*}{ Dummy: Ukraine } & 0.794 & 0.8 & 0.81 & 0.818 & 1.149 \\
\hline & {$[0.158]^{* * *}$} & {$[0.159]^{* * *}$} & {$[0.160]^{* * *}$} & {$[0.160]^{* * *}$} & {$[0.320]^{* * *}$} \\
\hline \multirow[t]{2}{*}{ Dummy: Russia } & 0.702 & 0.704 & 0.72 & 0.697 & 0.479 \\
\hline & {$[0.192]^{* * *}$} & {$[0.193]^{* * *}$} & {$[0.193]^{* * *}$} & {$[0.194]^{* * *}$} & {$[0.357]$} \\
\hline \multirow{2}{*}{ Dummy: Metal } & -0.129 & -0.135 & -0.109 & -0.113 & -0.212 \\
\hline & {$[0.187]$} & {$[0.188]$} & {$[0.190]$} & {$[0.190]$} & {$[0.231]$} \\
\hline \multirow[t]{2}{*}{ Dummy: Wood } & -0.4 & -0.395 & -0.364 & -0.37 & -0.466 \\
\hline & {$[0.276]$} & {$[0.276]$} & {$[0.278]$} & {$[0.278]$} & {$[0.318]$} \\
\hline \multirow[t]{2}{*}{ Dummy: Food } & -0.552 & -0.529 & -0.487 & -0.493 & -0.506 \\
\hline & {$[0.230]^{* *}$} & {$[0.231]^{* *}$} & {$[0.233]^{* *}$} & {$[0.233]^{* *}$} & {$[0.280]^{*}$} \\
\hline \multirow[t]{2}{*}{ Dummy: Cloth } & -0.743 & -0.733 & -0.683 & -0.688 & -0.641 \\
\hline & {$[0.241]^{* * *}$} & {$[0.242]^{* * *}$} & {$[0.243]^{* * *}$} & {$[0.243]^{* * *}$} & {$[0.285]^{* *}$} \\
\hline \multirow[t]{2}{*}{ Dummy: Construction } & 0.09 & 0.104 & 0.118 & 0.125 & 0.187 \\
\hline & [0.217] & {$[0.217]$} & [0.220] & [0.219] & [0.263] \\
\hline \multirow[t]{2}{*}{ Dummy: Chemical } & -0.111 & -0.106 & -0.073 & -0.08 & 0.074 \\
\hline & {$[0.252]$} & {$[0.251]$} & [0.255] & {$[0.254]$} & {$[0.282]$} \\
\hline \multirow[t]{2}{*}{ Dummy: Pulp and paper } & -0.036 & -0.041 & -0.013 & -0.021 & -0.07 \\
\hline & {$[0.317]$} & {$[0.314]$} & {$[0.316]$} & {$[0.316]$} & {$[0.366]$} \\
\hline \multirow[t]{2}{*}{ Dummy: Handcrafts } & -0.899 & -0.891 & -0.866 & -0.782 & -0.884 \\
\hline & {$[0.535]^{*}$} & {$[0.535]^{*}$} & {$[0.533]$} & [0.539] & {$[0.570]$} \\
\hline \multirow[t]{2}{*}{ Dummy: Electric } & -0.257 & -0.257 & -0.25 & -0.243 & -0.613 \\
\hline & {$[0.256]$} & {$[0.256]$} & [0.258] & {$[0.258]$} & {$[0.368]^{*}$} \\
\hline \multicolumn{2}{|l|}{ Experience in public sector } & & & & 0.06 \\
\hline & & & & & {$[0.161]$} \\
\hline \multirow[t]{2}{*}{ Financing from SOE } & & & & & 0.514 \\
\hline & & & & & {$[0.283]^{*}$} \\
\hline \multirow[t]{2}{*}{ Makes “protection”payments } & & & & & 0.37 \\
\hline & & & & & {$[0.207]^{*}$} \\
\hline \multirow[t]{2}{*}{ Constant } & -0.94 & -0.944 & 0.16 & -0.408 & -0.342 \\
\hline & {$[0.187]^{* * *}$} & {$[0.188]^{* * *}$} & [0.883] & [0.916] & [0.945] \\
\hline Observations & 954 & 944 & 940 & 939 & 822 \\
\hline
\end{tabular}


Log likelihood

$-312.17$

$-309.92$

$-307.71$

$-307.94$

$-227.63$

Note: Standard errors, in brackets, are robust to heteroscedasticity of unknown form. $* * *$ denotes statistically significant at the 1 percent level, ${ }^{* *}$ denotes statistically significant at the 5 percent level. * denotes statistically significant at the 10 percent level. 


\begin{tabular}{|c|c|c|c|c|c|c|}
\hline \multicolumn{7}{|c|}{$\begin{array}{l}\text { Table } 4 \\
\text { Determinants of Asset Stripping in Transition Economies: } \\
\text { The Role of Institutional Conditions (Probit Estimates) }\end{array}$} \\
\hline & (1) & $(2)$ & (3) & (4) & (5) & (6) \\
\hline \multirow[t]{2}{*}{ Firm size (full time employees) } & 0.002 & 0.002 & 0.003 & 0.002 & 0.002 & 0.003 \\
\hline & {$[0.001]^{* *}$} & {$[0.001]^{* *}$} & {$[0.001]^{* * *}$} & {$[0.001]^{*}$} & {$[0.001]^{*}$} & {$[0.001]^{* * *}$} \\
\hline \multirow[t]{2}{*}{ Year firm started operation } & 0.027 & 0.027 & 0.026 & 0.019 & 0.018 & 0.013 \\
\hline & {$[0.010]^{* * *}$} & {$[0.009]^{* * *}$} & {$[0.015]^{*}$} & {$[0.010]^{*}$} & {$[0.009]^{* *}$} & {$[0.009]$} \\
\hline \multirow[t]{2}{*}{ Unreported sales, \% of total } & 0.001 & & & & & \\
\hline & {$[0.003]$} & & & & & \\
\hline \multirow[t]{2}{*}{ Unreported wages, \% of total } & & -0.006 & & & & \\
\hline & & {$[0.003]^{*}$} & & & & \\
\hline \multirow[t]{2}{*}{ Unreported input costs,\% of total } & & & 0.006 & & & \\
\hline & & & {$[0.002]^{* *}$} & & & \\
\hline \multirow[t]{2}{*}{ Unreported exports, \% of total } & & & & 0.004 & & \\
\hline & & & & {$[0.002]^{* *}$} & & \\
\hline \multirow[t]{2}{*}{ Unreported imports, \% of total } & & & & & 0.003 & \\
\hline & & & & & {$[0.002]$} & \\
\hline Percentage of manager time & & & & & & 0.024 \\
\hline with government officials & & & & & & {$[0.004]^{* * *}$} \\
\hline \multirow{2}{*}{ Constant } & -2.95 & -2.816 & -3.388 & -2.213 & -2.129 & -2.269 \\
\hline & {$[0.883]^{* * *}$} & {$[0.873]^{* * *}$} & {$[1.407]^{* *}$} & {$[0.914]^{* *}$} & {$[0.845]^{* *}$} & {$[0.791]^{* * *}$} \\
\hline Country dummies? & No & No & No & No & No & No \\
\hline Industry dummies? & Yes & Yes & Yes & Yes & Yes & Yes \\
\hline Observations & 635 & 622 & 395 & 599 & 592 & 890 \\
\hline Log likelihood & -270.54 & -263.37 & -120.95 & -248.78 & -244.27 & -322.09 \\
\hline
\end{tabular}




\section{Table 5 \\ Determinants of Asset Stripping in Transition Economies: The Role of Profitability (Probit Estimates)}

\begin{tabular}{|l|l|l|l|l|}
\hline & $(1)$ & $(2)$ & $(3)$ & $(4)$ \\
\hline After-tax profit $1^{\text {st }}$ year (\% inv.) & 0.085 & 0.622 & 0.649 & 0.568 \\
\hline & {$[0.044]^{*}$} & {$[0.228]^{* * *}$} & {$[0.237]^{* * *}$} & {$[0.246]^{* *}$} \\
\hline Squared: After-tax profit 1 $1^{\text {st }}$ year (\% inv.) & & -0.067 & -0.067 & -0.049 \\
\hline & & {$[0.029]^{* *}$} & {$[0.030]^{* *}$} & {$[0.031]^{*}$} \\
\hline Year firm started operation & -0.008 & -0.006 & -0.013 & -0.014 \\
\hline & {$[0.009]$} & {$[0.009]$} & {$[0.012]$} & {$[0.012]$} \\
\hline Firm size (full time employees) & & & 0.003 & 0.003 \\
\hline & & & {$[0.001]^{* * *}$} & {$[0.001]^{* * *}$} \\
\hline Experience in public sector & & & & 0.009 \\
\hline & & & & {$[0.165]$} \\
\hline Financing from state enterprise & & & & 0.478 \\
\hline & & & & {$[0.280]^{*}$} \\
\hline Makes “protection”payments & & & & 0.417 \\
\hline & & & & {$[0.215]^{*}$} \\
\hline Constant & -0.516 & -1.638 & -1.256 & -1.155 \\
\hline & {$[0.825]$} & {$[0.951]$} & {$[1.210]$} & {$[1.252]$} \\
\hline Country dummies? & Yes & Yes & Yes & Yes \\
\hline Industry dummies? & Yes & Yes & Yes & Yes \\
\hline Observations & 943 & 943 & 925 & 808 \\
\hline Log likelihood & -313.33 & -311.27 & -302.23 & -220.79 \\
\hline Note: Stand & & & & \\
\hline
\end{tabular}

Note: Standard errors, in brackets, are robust to heteroscedasticity of unknown form. denotes statistically significant at the 1 percent level, ** denotes statistically significant at the 5 percent level. * denotes statistically significant at the 10 percent level. 


\begin{tabular}{|c|c|c|c|}
\hline \multicolumn{4}{|c|}{$\begin{array}{l}\text { Table } 6 \\
\text { Do Firms Using Stripped Assets Grow Faster? } \\
\text { Firm Growth Measured as Employment Growth (Ordinary Least Square Estimates) }\end{array}$} \\
\hline & $(1)$ & $(2)$ & (3) \\
\hline \multirow[t]{2}{*}{ Asset stripping as share of physical capital from SOE } & & 0.382 & 0.447 \\
\hline & & [0.237] & {$[0.300]$} \\
\hline \multirow[t]{2}{*}{ Firm size (full time employees) } & -0.025 & -0.026 & -0.027 \\
\hline & {$[0.008]^{* * *}$} & {$[0.007]^{* * *}$} & {$[0.007]^{* * *}$} \\
\hline \multirow[t]{2}{*}{ Year firm started operation } & -0.167 & -0.165 & -0.153 \\
\hline & {$[0.055]^{* * *}$} & {$[0.055]^{* * *}$} & {$[0.056]^{* *}$} \\
\hline \multirow[t]{2}{*}{ Dummy: Poland } & 2.25 & 2.289 & 2.708 \\
\hline & {$[0.600]^{* * *}$} & {$[0.605]^{* * *}$} & {$[0.693]^{* * *}$} \\
\hline \multirow[t]{2}{*}{ Dummy: Slovakia } & 0.838 & 0.874 & 1.223 \\
\hline & {$[0.391]^{* *}$} & {$[0.393]^{* *}$} & {$[0.441]^{* * *}$} \\
\hline \multirow[t]{2}{*}{ Dummy: Ukraine } & -2.507 & -2.681 & -2.474 \\
\hline & {$[0.272]^{* * *}$} & {$[0.278]^{* * *}$} & {$[0.660]^{* * *}$} \\
\hline \multirow[t]{2}{*}{ Dummy: Russia } & -2.016 & -2.11 & -1.987 \\
\hline & {$[0.312]^{* * *}$} & {$[0.320]^{* * *}$} & {$[0.717]^{* * *}$} \\
\hline \multirow[t]{2}{*}{ Dummy: Metal } & -0.29 & -0.279 & -0.389 \\
\hline & [0.547] & {$[0.548]$} & {$[0.674]$} \\
\hline \multirow[t]{2}{*}{ Dummy: Wood } & -0.113 & -0.071 & -0.199 \\
\hline & [0.637] & [0.639] & {$[0.734]$} \\
\hline \multirow[t]{2}{*}{ Dummy: Food } & -0.349 & -0.31 & -0.417 \\
\hline & [0.498] & {$[0.501]$} & [0.639] \\
\hline \multirow[t]{2}{*}{ Dummy: Cloth } & 0.214 & 0.275 & 0.091 \\
\hline & [0.543] & {$[0.548]$} & [0.672] \\
\hline \multirow[t]{2}{*}{ Dummy: Construction } & -0.863 & -0.866 & -1.042 \\
\hline & [0.592] & {$[0.595]$} & {$[0.765]$} \\
\hline \multirow[t]{2}{*}{ Dummy: Chemical } & -0.137 & -0.16 & -0.339 \\
\hline & {$[0.595]$} & {$[0.601]$} & {$[0.726]$} \\
\hline \multirow[t]{2}{*}{ Dummy: Pulp and paper } & 0.77 & 0.765 & 0.86 \\
\hline & [1.180] & [1.184] & [1.341] \\
\hline \multirow[t]{2}{*}{ Dummy: Handcrafts } & 1.456 & 1.539 & 1.885 \\
\hline & [2.719] & {$[2.723]$} & [3.207] \\
\hline \multirow[t]{2}{*}{ Dummy: Electric } & -0.934 & -0.92 & -1.284 \\
\hline & {$[0.590]$} & {$[0.595]$} & {$[0.743]^{*}$} \\
\hline \multicolumn{2}{|l|}{ Experience in public sector } & & 1.262 \\
\hline & & & {$[0.436]^{* * *}$} \\
\hline \multirow[t]{2}{*}{ Financing from state enterprise } & & & 0.695 \\
\hline & & & [0.431] \\
\hline \multirow[t]{2}{*}{ Makes “protection” payments } & & & -0.477 \\
\hline & & & [0.562] \\
\hline \multirow[t]{2}{*}{ Constant } & 18.645 & 18.023 & 15.8 \\
\hline & {$[5.159]^{* *}$} & {$[5.185]^{* *}$} & {$[5.349]^{* * *}$} \\
\hline Observations & 937 & 935 & 819 \\
\hline Adjusted R-squared & 0.15 & 0.15 & 0.13 \\
\hline
\end{tabular}




\section{DAVIDSON INSTITUTE WORKING PAPER SERIES - Most Recent Papers}

The entire Working Paper Series may be downloaded free of charge at: www.wdi.bus.umich.edu

CURRENT AS OF 8/18/05

\begin{tabular}{|c|c|c|}
\hline Publication & Authors & Date \\
\hline $\begin{array}{l}\text { No. 786: The Determinants of Asset Stripping: Theory and Evidence } \\
\text { From the Transition Economies }\end{array}$ & $\begin{array}{l}\text { Nauro F. Campos and Francesco } \\
\text { Giovannoni }\end{array}$ & Aug. 2005 \\
\hline $\begin{array}{l}\text { No. 785: How to Catch Foreign Fish? FDI and Privatization in EU } \\
\text { Accession Countries }\end{array}$ & $\begin{array}{l}\text { Bruno Merlevede and Koen } \\
\text { Schoors }\end{array}$ & Aug. 2005 \\
\hline $\begin{array}{l}\text { No. 784: Does the World Bank have any impact on human development } \\
\text { of the poorest countries? Some preliminary evidence from Africa }\end{array}$ & Sumon Kumar Bhaumik & Aug. 2005 \\
\hline $\begin{array}{l}\text { No. 783: Comparative social capital: Networks of entrepreneurs and } \\
\text { investors in China and Russia }\end{array}$ & Bat Batjargal & July 2005 \\
\hline $\begin{array}{l}\text { No. 782: Exchange Rate Regimes, Foreign Exchange Volatility and } \\
\text { Export Performance in Central and Eastern Europe: Just Another Blur } \\
\text { Project? }\end{array}$ & $\begin{array}{l}\text { Balázs Égert and Amalia } \\
\text { Morales-Zumaquero }\end{array}$ & July 2005 \\
\hline $\begin{array}{l}\text { No. 781: Equilibrium Exchange Rate in the Czech Republic: How Good } \\
\text { is the Czech BEER? }\end{array}$ & Ian Babetskii and Balázs Égert & July 2005 \\
\hline $\begin{array}{l}\text { No. 780: Autonomy and Performance of Foreign Subsidiaries in five } \\
\text { Transition Countries }\end{array}$ & $\begin{array}{l}\text { Urmas Varblane, Katrin Männik, } \\
\text { and Helena Hannula }\end{array}$ & July 2005 \\
\hline $\begin{array}{l}\text { No. 779: The Political Economy of Industrial Policy in China: The Case } \\
\text { of Aircraft Manufacturing }\end{array}$ & Andrea Goldstein & July 2005 \\
\hline $\begin{array}{l}\text { No. 778: Bank Supervision Russian style: Rules versus Enforcement } \\
\text { and Tacit Objectives }\end{array}$ & $\begin{array}{l}\text { Sophie Claeys, Gleb Lanine and } \\
\text { Koen Schoors }\end{array}$ & June 2005 \\
\hline No. 777: Labor Market Trends and Institutions in Belarus & $\begin{array}{l}\text { Zuzana Brixiova and Vera } \\
\text { Volchok }\end{array}$ & June 2005 \\
\hline $\begin{array}{l}\text { No. 776: Can Vietnam Achieve One of its Millennium Development } \\
\text { Goals? An analysis of schooling dropouts of children }\end{array}$ & $\begin{array}{l}\text { Vo Tri Thanh And Trinh Quang } \\
\text { Long }\end{array}$ & June 2005 \\
\hline $\begin{array}{l}\text { No. 775: Is The Link Between Reforms And Growth Spurious? A } \\
\text { Comment }\end{array}$ & Tomasz Mickiewicz & May 2005 \\
\hline $\begin{array}{l}\text { No. 774: The Risk Aversion of Banks in Emerging Credit markets: } \\
\text { Evidence from India }\end{array}$ & $\begin{array}{l}\text { Sumon Kumar Bhaumik and } \\
\text { Jenifer Piesse }\end{array}$ & May 2005 \\
\hline $\begin{array}{l}\text { No. 773: Organized Labor and Restructuring: Coal Mines in the Czech } \\
\text { Republic and Romania }\end{array}$ & $\begin{array}{l}\text { Jan Bruha, Delia Ionascu, and } \\
\text { Byeongju Jeong }\end{array}$ & May 2005 \\
\hline $\begin{array}{l}\text { No. 772: Is Political Risk Company-Specific? The Market Side of the } \\
\text { Yukos Affair }\end{array}$ & $\begin{array}{l}\text { Alexei Goriaev and Konstantin } \\
\text { Sonin }\end{array}$ & May 2005 \\
\hline $\begin{array}{l}\text { No. 771: Non-Linear Exchange Rate Dynamics in Target Zones: A } \\
\text { Bumpy Road Towards A Honeymoon }\end{array}$ & $\begin{array}{l}\text { Jesús Crespo-Cuaresma, Balázs } \\
\text { Égert, and Ronald MacDonald }\end{array}$ & May 2005 \\
\hline $\begin{array}{l}\text { No. 770: Equilibrium Exchange Rates in Southeastern Europe, Russia, } \\
\text { Ukraine and Turkey: Healthy or (Dutch) Diseased? }\end{array}$ & Balázs Égert & May 2005 \\
\hline $\begin{array}{l}\text { No. 769: Equilibrium Exchange Rates in Central and Eastern Europe: A } \\
\text { Meta-Regression Analysis }\end{array}$ & Balázs Égert and László Halpern & May 2005 \\
\hline $\begin{array}{l}\text { No. 768: Testing for inflation convergence between the Euro Zone } \\
\text { and its CEE partners }\end{array}$ & Imed Drine and Christophe Rault & Apr. 2005 \\
\hline $\begin{array}{l}\text { No. 767: Labor Mobility during Transition: Evidence from the Czech } \\
\text { Republic }\end{array}$ & Jan Fidrmuc & Apr. 2005 \\
\hline $\begin{array}{l}\text { No. 766: Formation of social capital in Central and Eastern Europe: } \\
\text { Understanding the gap vis-à-vis developed countries }\end{array}$ & Jan Fidrmuc and Klarita Gërxhani & Apr. 2005 \\
\hline $\begin{array}{l}\text { No. 765: Do Regional Integration Agreements Increase Business-Cycle } \\
\text { Convergence? Evidence From APEC and NAFTA }\end{array}$ & $\begin{array}{l}\text { Viviana Fernandez and Ali M. } \\
\text { Kutan }\end{array}$ & Apr. 2005 \\
\hline $\begin{array}{l}\text { No. 764: State Regulations, Job Search and Wage Bargaining: A Study } \\
\text { in the Economics of the Informal Sector }\end{array}$ & Maxim Bouev & Apr. 2005 \\
\hline $\begin{array}{l}\text { No. 763: The Feldstein-Horioka Puzzle Revisited: An “European- } \\
\text { Regional” Perspective }\end{array}$ & $\begin{array}{l}\text { Jérôme Hericourt and Mathilde } \\
\text { Maurel }\end{array}$ & Apr. 2005 \\
\hline $\begin{array}{l}\text { No. 762: Transatlantic Differences in Labour Markets Changes in Wage } \\
\text { and Non-Employment Structures in the 1980s and the 1990s }\end{array}$ & Patrick A. Puhani & Mar. 2005 \\
\hline $\begin{array}{l}\text { No. 761: Resolution, Recovery and Survival: The Evolution of Payment } \\
\text { Disputes in Post-Socialist Europe }\end{array}$ & William Pyle & Mar. 2005 \\
\hline
\end{tabular}

